\title{
Relationships between selected tree characteristics and the properties of juvenile wood in Scots pine (Pinus sylvestris L.)
}

\author{
Arkadiusz Tomczak \\ Poznań University of Life Sciences, Department of Forest Utilisation, ul. Wojska Polskiego 71A, 60-625 Poznań, Poland.
}

Tel. +48 6184877 56; e-mail: arkadiusz.tomczak@up.poznan.pl

\begin{abstract}
The aim of this study was to determine relationships between selected properties of juvenile wood and characteristics of the stem and crown of Scots pine. Analyses were conducted in northern Poland on eight mature pine monocultures. Nine trees were selected in each experimental site and their stems were divided into five sections. The centers of the sections were established at a height of $1.3 \mathrm{~m}$ from the tree base and at points corresponding to 20, 40,60 and $80 \%$ tree height. Samples were taken from these locations, and these samples were prepared for analyses of basic density, compressive strength along the grain and static bending, as well as the modulus of elasticity during bending. The mean height of the investigated group of trees was $26.0 \mathrm{~m}$ with an average diameter breast high of $33.6 \mathrm{~cm}$. The mean crown depth was $7.8 \mathrm{~m}$ and crown diameter was $3.6 \mathrm{~m}$, and the mean basic density $(Q u)$ of juvenile pine wood was 416 $\mathrm{kg} / \mathrm{m}^{3}$. The average compressive strength along the grain $(C S)$ was determined to be $22.3 \mathrm{MPa}$, while static bending strength $(B S)$ was $45.8 \mathrm{MPa}$. The recorded modulus of elasticity $(M O E)$ was $4726 \mathrm{MPa}$.

Both in general terms and when dividing stems into sections, the wood properties correlated with tree characteristics to various degrees. All indexes were negative indicating that trees of greater dimensions produce juvenile wood of inferior quality. Properties of juvenile wood formed during various periods of tree life were mostly related to diameter breast high and crown depth. They were also correlated with tree height, but only to a limited extent. In contrast, properties of wood from the middle stem sections were significantly correlated with crown diameter.
\end{abstract}

Key words: basic density, strength perpendicular to grain, bending strength, modulus of elasticity, breast height diameter, tree height, crown length, crown diameter

\section{Introduction}

Properties of wood result first of all from its structure (Verkasalo 1992; Hanrup et al. 2001). Structure of wood, without features conditioned genetically, is on the other hand a result of growth conditions and tree development including inter alia site type and treatments breeding (Pazdrowski and Spława-Neyman 1997). In this special system of interactions, features (dimensions) of a stem and crown occupy a place between conditions of growth and tree's development and structure and features of wood. According to Jelonek (2013), there is no relationship between wood density and Scots pine stem and crown features. The author states, however, the relationship of stem and crown features in case of compressive strength along fibres and static bending strength. In relation to diameter breast height (dbh) and crown length, relations mentioned above are reverse and in relation to tree's height and crown's width, they are directly proportional. Wąsik (2000), after analysing relations between chosen parameters of crown and features of Coast Douglas-fir wood macrostructure, stated that trees with longer and wider crown had significantly wider annual increments than increments of trees with shorter and narrower crowns. At coniferous, bigger width of annu- 
al increment in thickness means smaller share of latewood and worse technical parameters of wood (Fabisiak 2005). Smaller crown means also smaller weight resting on stem. Stem's cross-section may have consequently smaller area than in case of trees with big and heavy crowns. It is an effect of a process depending on forming maximally durable structure with the lowest possible energy investment (Zajączkowska 2006).

According to many researches, the influence of tree's crown on structure forming and wood properties is particularly vivid in juvenile wood (Pazdrowski and Jakubowski 2000; Amarasekara and Denne 2002; Jakubowski 2004; Mansfield et al. 2007). Juvenile wood is a wood tissue placed in central part of stem's cross-section, within a dozen or so annual increments to thickness (Mutz et al. 2004; Fries and Ericsson 2009). Juvenile wood is characterised with smaller share of cellulose, bigger inclination angle of fibrils in cell walls and smaller share of latewood. All those features have influence on mechanical properties. That is why juvenile wood is mechanically weaker than mature wood (Zobel and Sprague 1998; Pazdrowski 2004). In case of pine, a difference between juvenile and mature wood default density amounts around $25 \mathrm{~kg} / \mathrm{m}^{3}$. Compressive strength along fibres of juvenile wood is smaller by around $3 \mathrm{MPa}$, and static bending strength smaller by around $7 \mathrm{MPa}$ (Tomczak and Jelonek 2012). Juvenile wood on stem's longitudinal section occurs on its whole length, that is why the top part of tree may be built exclusively from this type of tissue. Mature wood, which surrounds juvenile wood with a ring, occurs in stem's base. With age, its range increases and with mature trees, it amounts around $85 \%$ of tree's height (Tomczak et al. 2007a). The tree's features such as dbh, height and volume strongly correlate with juvenile wood share and mature wood share (Tomczak et al. 2005; Tomczak et al. 2006). A special influence of crown on forming of tree's tissue may constitute the fact that in case of its partial reduction (artificial pruning) share of juvenile wood in trees stem was lower than in control trees in which assimilation apparatus was not reduced (Pazdrowski et al. 2007). As Hejnowicz (2002) states, juvenile wood is produced under strong influence of leaves closeness. Time of its formation in stem depends on how low tree's crown reaches. Similarly states Kučera (1994), who links the fact of juvenile wood forming with dynamics of trees annual increment to height.

Between juvenile wood from butt end part and from top part of stem occur vivid differences in macro-structural construction (Tomczak et al. 2007b). They are probably connected with changes occurring in tree's bi- omechanical system during its growth and development and with effect of tendency for forming maximally durable structure (connected with tree's dimensions, especially with dimensions in mature age) with the smallest energetic cost. Having in mind above supposition, it was assumed in study that chosen properties of juvenile wood and some features of stem and crown are correlated.

\section{Research methodology}

\section{Choice and measurements on experimental plots}

Research was conducted in the northern part of Poland (Szczecinek Regional Directorate of State Forests) in eight mature pine's monocultures. Forest stands chosen for research grew in conditions of fresh mixed coniferous forest and were characterised with I site index and broken-crown closure stocking from 0.7 to 1.1. Their age ranged from 82 and 89 years, average dbh ranged from 31 and $37 \mathrm{~cm}$, and height between 24 and $27 \mathrm{~m}$.

In each forest stand, sample plots were set, on which the features of all growing trees, i.e. height (m), dbh in two opposite directions $(\mathrm{cm})$, height of first living branch seating $(\mathrm{m})$ and crown's diameter in two opposite directions $(\mathrm{m})$, were measured. Measurements of height and seating of first living branch were made with the use of Nikon Forestry hypsometer with rounding to $0.1 \mathrm{~m}$. Dbh in bark $\left(d_{1.3}\right)$ was measured twice with caliper, with rounding to $0.5 \mathrm{~cm}$, and then the result was averaged. Crown's diameter $\left(d_{k}\right)$ was defined on the basis of two averaged measurements, performed with rangefinder with accuracy to $0.1 \mathrm{~m}$. After obtaining data, i.e. height measurement and seating of living crown, living crown length $\left(l_{k}\right)$ was calculated by subtracting the height of the first living branch seating of a compact crown from the tree's height $\left(h_{d}\right)$.

\section{Choice of model trees and materials for laboratory research}

On the basis of characteristics of trees growing on sample plots, chosen were model trees using Urich I dendrometric method. Due to trees diversity to weight, thickness and size of crown for model trees selection, Kraft's classification (1884) was used. For research, chosen were trees without any vivid anomalies in stem's shape and with symmetrically developed crown were chosen. On each plot selected were nine trees. Jointly, the research covered 72 model trees.

After cutting the trees, the stems of model trees were divided to five sections. The centre of the first section 
was marked on $1.3 \mathrm{~m}$ from stem's base, and next in points corresponding to $20 \%, 40 \%, 60 \%$ and $80 \%$ of stem length. From those places, a material was collected on which tests were performed for studying the chosen wood properties. Test included part of stem between core and circuit, on two opposite radius-oriented east-west to world directions. First sample was set $1 \mathrm{~cm}$ from the core. Collected samples were numbered in sequence. In next stages, only two samples placed closest to the core, with sample centres placed 2 and $4 \mathrm{~cm}$ from the core, were included. Such a proceeding allowed conducting research on materials only from the juvenile part of cross-section of the stem.

\section{Laboratory research}

Four wood properties were examined: basic density $(Q u)$, compressive strength perpendicular to grain $(C S)$, static bending strength $(B S)$ and modulus of elasticity in bending $(M O E)$. Basic density $\left(\mathrm{kg} / \mathrm{m}^{3}\right)$ was defined on samples of dimensions $20 \mathrm{~mm} \times 20 \mathrm{~mm} \times 30 \mathrm{~mm}$, as a relation of mass in state of absolute dry to volume in state of maximum swell $(w>30 \%)$. Maximum swell of pellicles (wood humidity over $30 \%$ ) was obtained by submergence of samples in water, until the moment of reaching dimensional stability, i.e. until the increments of particular samples' dimensions measured in 72-h gap were equal or smaller than $0.2 \mathrm{~mm}$. The mass of samples was defined with the use of laboratory scale with accuracy to $0.001 \mathrm{~g}$. For defying linear dimensions of samples, a slide caliper was used, rounding results to $0.01 \mathrm{~mm}$ (PN-77/D-04101).

Mechanical properties were defined on the basis of endurance tests. For obtained results to be close to wood properties by which growing trees stems are characterised, analysis were made at humidity higher than $30 \%$ - above fibre saturation point. Compressive strength along fibres (MPa) was defined on samples with standardised dimensions $20 \mathrm{~mm} \times 20 \mathrm{~mm} \times 30 \mathrm{~mm}$, whereas static bending strength (MPa) and modulus of elasticity in bending (MPa) on samples of dimensions $20 \mathrm{~mm} \times 20 \mathrm{~mm} \times 300 \mathrm{~mm}$ according to procedure's included in norms: PN-63/D-04117; PN-77/D-04103; PN-79/D-04102, with the above-described modification concerning wood humidity.

\section{Statistical analysis}

Each of wood properties and trees features was characterised with basic position and dispersion measures: mean, quartiles, minimum and maximum value, standard deviation and variation coefficient. Analysed were jointly 1320 samples for $Q u$ and $C S$ establishment and 1278 samples for $B S$ and $M O E$ values establishment. Each of those sets was additionally divided to five subsets, representing individual zones of stem and was, respectively, characterised statistically. Relations between trees features and wood properties defined were with the use of correlation coefficients. Adopted was that coefficient value from 0.0 to 0.2 is a very weak correlation, $0.2-0.4$ weak correlation, $0.4-0.6$ moderate correlation, $0.6-0.8$ strong and from 0.8 to 1.0 very strong. Calculations were made with the use of statistical package Statistica (Statasoft, Inc.)

\section{Research results}

\section{Trees' features characteristic and juvenile wood properties}

The average height of trees of examined group was $26.0 \mathrm{~m}$ (median $25.8 \mathrm{~m}$ ). Average dbh equalled 33.6 $\mathrm{cm}$ (median $33.5 \mathrm{~cm}$ ). Length of crown was $7.8 \mathrm{~m}$ and width $3.6 \mathrm{~m}$, median values for those features were, respectively, 8.1 and $3.8 \mathrm{~m}$. The smallest variability was in case of height, and the biggest was in crown width. Crown's features were characterised with greater variability than stem's features (Table 1).

Average basic density $(Q u)$ of pine's juvenile wood was $416 \mathrm{~kg} / \mathrm{m}^{3}$. Average compressive strength along fibres $(C S)$ was defined on $22.3 \mathrm{MPa}$ level, and static bending strength $(B S)$ was $45.8 \mathrm{MPa}$. The value of elasticity modulus (MOE) was $4726 \mathrm{MPa}$. Median value of all features was very close to average values. The smallest variability coefficient was stated with $Q u$, and the biggest in case of MOE (Table 2).

On longitudinal section of stem, the average value of basic density ranged from 385 to $473 \mathrm{~kg} / \mathrm{m}^{3}$ (difference $88 \mathrm{~kg} / \mathrm{m}^{3}-18.6 \%$ ). The highest value was stated on $\mathrm{dbh}$ level and the smallest on level corresponding to $60 \%$ of tree's height. Median describing $Q u$ had a value close to average, variability coefficient ranged from around 7 to around $11 \%$. CS value ranged from 20.2 to $24.8 \mathrm{MPa}$ (difference $4.6 \mathrm{MPa}-18.6 \%$ ), $B S$ between 39.5 and 53.5 $\mathrm{MPa}$ (difference $14.0 \mathrm{MPa}-26.1 \%$ ) and $M O E$ between 3872 and $5556 \mathrm{MPa}$ (difference $1684 \mathrm{MPa}-30.3 \%$ ). Values of wood mechanical properties, unlike $Q u$ value, decreased systematically with an increase of place of measurement distance from stem's base. Median values were also very close to averages. Results were not interrupted, therefore, by samples with outlier values. As for mechanical properties, with the biggest variability was characterised MOE, with the smallest - CS (Table 3). 
Table 1. Statistical characteristics of the tree features

\begin{tabular}{lcccccccc}
\hline \hline \multicolumn{1}{c}{ Feature } & Mean & Median & Min & Max & $\mathrm{Q}_{25}$ & $\mathrm{Q}_{75}$ & $\mathrm{SD}$ & $\mathrm{VC}(\%)$ \\
\hline$h_{d}(\mathrm{~m})$ & 26.0 & 25.8 & 18.5 & 33.8 & 23.8 & 28.3 & 2.8 & 10.85 \\
$d_{1.3}(\mathrm{~cm})$ & 33.6 & 33.5 & 21.0 & 45.0 & 29.5 & 40.0 & 6.9 & 20.67 \\
$l_{k}(\mathrm{~m})$ & 7.8 & 8.1 & 2.9 & 14.2 & 6.0 & 9.6 & 2.3 & 30.10 \\
$d_{k}(\mathrm{~m})$ & 3.8 & 3.6 & 1.6 & 7.9 & 2.6 & 5.0 & 1.6 & 40.65 \\
\hline
\end{tabular}

$h_{d}$ - tree height; $d_{1,3}-\mathrm{dbh} ; l_{k}-$ crown length; $d_{k}-$ crown diameter; $\mathrm{SD}-$ standard deviation; $\mathrm{Q}_{25}-$ lower quartile; $\mathrm{Q}_{75}-$ upper quartile; VC - variability coefficient

Table 2. Statistical characteristics of the wood features

\begin{tabular}{lcccccccc}
\hline \multicolumn{1}{c}{ Feature } & Mean & Median & Min & Max & $\mathrm{Q}_{25}$ & $\mathrm{Q}_{75}$ & $\mathrm{SD}$ & $\mathrm{VC}$ \\
\hline$Q u\left(\mathrm{~kg} / \mathrm{m}^{3}\right)$ & 416 & 415 & 356 & 501 & 397 & 432 & 29 & 7.00 \\
$C S(\mathrm{MPa})$ & 22.3 & 22.4 & 16.5 & 27.9 & 20.9 & 23.8 & 2.4 & 10.59 \\
$B S(\mathrm{MPa})$ & 45.8 & 46.4 & 33.0 & 60.5 & 41.6 & 49.6 & 6.0 & 13.17 \\
$M O E(\mathrm{MPa})$ & 4726 & 4667 & 3089 & 6567 & 4260 & 5288 & 732 & 15.49 \\
\hline
\end{tabular}

$Q u$ - basic density; $C S$ - strength perpendicular to grain; $B S$ - bending strength; $M O E$ - modulus of elasticity; SD - standard deviation; $\mathrm{Q}_{25}$ - lower quartile; $\mathrm{Q}_{75}$ - upper quartile; $\mathrm{VC}$ - variability coefficient

Table 3. Statistical characteristics of features of the juvenile wood from different height levels of stem

\begin{tabular}{|c|c|c|c|c|c|c|c|c|c|}
\hline Feature & $\begin{array}{l}\text { Height } \\
\text { level* }\end{array}$ & Mean & Median & Min & Max & $\mathrm{Q}_{25}$ & $\mathrm{Q}_{75}$ & SD & $\mathrm{VC}$ \\
\hline \multirow{5}{*}{$Q u\left(\mathrm{~kg} / \mathrm{m}^{3}\right)$} & $d_{1.3}$ & 473 & 475 & 358 & 613 & 446 & 504 & 51 & 10.72 \\
\hline & $20 \%$ & 423 & 421 & 333 & 619 & 389 & 447 & 44 & 10.38 \\
\hline & $40 \%$ & 399 & 398 & 335 & 499 & 380 & 420 & 33 & 8.37 \\
\hline & $60 \%$ & 385 & 385 & 339 & 454 & 364 & 403 & 28 & 7.34 \\
\hline & $80 \%$ & 396 & 392 & 325 & 564 & 366 & 415 & 42 & 10.68 \\
\hline \multirow{5}{*}{$C S(\mathrm{MPa})$} & $d_{1.3}$ & 24.79 & 24.65 & 14.82 & 35.50 & 21.96 & 27.70 & 4.08 & 16.47 \\
\hline & $20 \%$ & 23.19 & 23.17 & 16.31 & 30.34 & 21.47 & 25.34 & 2.89 & 12.45 \\
\hline & $40 \%$ & 22.16 & 22.12 & 16.21 & 31.50 & 20.64 & 23.61 & 2.88 & 12.99 \\
\hline & $60 \%$ & 20.66 & 20.47 & 15.90 & 28.84 & 18.63 & 21.93 & 2.67 & 12.90 \\
\hline & $80 \%$ & 20.17 & 20.07 & 14.81 & 29.16 & 17.97 & 21.67 & 2.86 & 14.16 \\
\hline \multirow{5}{*}{$B S(\mathrm{MPa})$} & $d_{1.3}$ & 53.51 & 53.57 & 34.54 & 73.76 & 47.34 & 58.33 & 8.64 & 16.15 \\
\hline & $20 \%$ & 48.57 & 48.53 & 31.32 & 64.09 & 44.77 & 54.64 & 7.66 & 15.76 \\
\hline & $40 \%$ & 46.00 & 45.85 & 29.43 & 67.13 & 40.35 & 50.28 & 7.44 & 16.18 \\
\hline & $60 \%$ & 41.70 & 40.95 & 30.23 & 62.16 & 37.23 & 45.12 & 6.43 & 15.42 \\
\hline & $80 \%$ & 39.52 & 38.36 & 26.23 & 56.37 & 35.16 & 44.30 & 6.32 & 16.00 \\
\hline \multirow{5}{*}{$M O E(\mathrm{MPa})$} & $d_{1.3}$ & 5556 & 5688 & 3196 & 7924 & 5043 & 6110 & 1041 & 18.74 \\
\hline & $20 \%$ & 5086 & 5143 & 2846 & 7523 & 4560 & 5744 & 934 & 18.37 \\
\hline & $40 \%$ & 4755 & 4734 & 2921 & 8734 & 4106 & 5181 & 972 & 20.43 \\
\hline & $60 \%$ & 4290 & 4292 & 2931 & 6959 & 3801 & 4628 & 745 & 17.36 \\
\hline & $80 \%$ & 3872 & 3859 & 2357 & 5409 & 3477 & 4394 & 671 & 17.32 \\
\hline
\end{tabular}

* - the distance of wood sample of the base of the stem: $d_{1.3}-$ of $1.3 \mathrm{~m}, 20 \%, 40 \%, 60 \%, 80 \%$ - of the length of stem.

Symbols as in the Table 2 
Table 4. Correlation between the trees features and the juvenile wood features (coefficients only statistically significant at $p<0.05$ are listed)

\begin{tabular}{|c|c|c|c|c|c|}
\hline \multirow[t]{2}{*}{ Height level } & \multirow{2}{*}{$\begin{array}{c}\text { Features of } \\
\text { juvenile wood }\end{array}$} & \multicolumn{4}{|c|}{ Features of trees } \\
\hline & & $h_{d}$ & $d_{1.3}$ & $l_{k}$ & $d_{k}$ \\
\hline \multirow{4}{*}{$\begin{array}{l}\text { Average for all } \\
\text { stem }\end{array}$} & $Q u$ & & -0.4366 & -0.3408 & \\
\hline & $C S$ & -0.3133 & -0.5895 & -0.4592 & -0.2396 \\
\hline & $B S$ & & -0.5064 & -0.4048 & \\
\hline & $M O E$ & -0.2341 & -0.5922 & -0.4655 & -0.275 \\
\hline \multirow[t]{4}{*}{$\mathrm{d}_{1.3}$} & $Q u$ & & & & \\
\hline & $C S$ & -0.2369 & -0.4343 & -0.3275 & \\
\hline & $B S$ & & -0.2906 & & \\
\hline & $M O E$ & & -0.4422 & -0.3257 & \\
\hline \multirow[t]{4}{*}{$20 \%$} & $Q u$ & -0.2606 & -0.4968 & -0.3017 & \\
\hline & $C S$ & -0.2495 & -0.5494 & -0.3394 & \\
\hline & $B S$ & & -0.4362 & -0.327 & -0.2893 \\
\hline & $M O E$ & & -0.5447 & -0.4165 & -0.2817 \\
\hline \multirow[t]{4}{*}{$40 \%$} & $Q u$ & & -0.3952 & -0.2891 & -0.2839 \\
\hline & $C S$ & -0.3173 & -0.4125 & -0.3537 & -0.2252 \\
\hline & $B S$ & & -0.3943 & -0.307 & -0.2652 \\
\hline & $M O E$ & & -0.4496 & -0.3453 & -0.302 \\
\hline \multirow[t]{4}{*}{$60 \%$} & $Q u$ & & -0.3109 & -0.3044 & -0.2591 \\
\hline & $C S$ & -0.2393 & -0.4282 & -0.3519 & -0.2913 \\
\hline & $B S$ & & -0.4117 & -0.2922 & -0.2574 \\
\hline & $M O E$ & & -0.382 & -0.2767 & -0.3787 \\
\hline \multirow[t]{4}{*}{$80 \%$} & $Q u$ & & & & \\
\hline & $C S$ & & & & \\
\hline & $B S$ & & & & \\
\hline & $M O E$ & & -0.2466 & & \\
\hline
\end{tabular}

$h_{d}-$ tree height, $d_{1.3}-$ DBH inside bark, $l_{k}-$ length of alive crown, $d_{k}-$ crown diameter. Other symbols as in the Table 3.

\section{Relations between trees' features and juvenile wood properties}

On the basis of analysis of relations between trees' features and wood properties defined as average values for whole stem stated was that properties that were relevantly connected with considered trees features were $C S$ and $M O E$. Both properties correlated strongly with $d_{1.3}, Q_{u}$ correlated moderately with $d_{1.3}$ and weakly with $l_{k}$, whereas $B S$ moderately correlated both with $d_{1.3}$ and $l_{k}$. Tree's features that relevantly $(p>0.05)$ correlated with all properties of wood were dbh and length of crown (Table 4).
Stated was, by examining relations between tree's features and wood properties in different shaft's parts, that on $\mathrm{dbh}$ level the strongest relation, statistically significant $\left(\mathrm{p}<0.05\right.$ ), was between $d_{1.3}$ and MOE (moderate correlation). In this part of shaft, $Q u$ did not correlate with any tree's features, CS was weakly correlated with $h_{d}$, moderately with $d_{1.3}$ and weakly with $l_{k}$ (Table 4 ). In part of shaft corresponding to $20 \%$ of tree's height, with dbh the strongest connected was CS, and with crown length - MOE. The tree's height significantly co-depended $Q u$ and $C S$, and on crown's width $B S$ and $M O E(p<0.05$; Table 4$)$.

At point corresponding to $40 \%$ of tree's height, $d_{1.3}$ and $l_{k}$ statistically significantly $(p<0.05)$ correlated with 
all analysed wood properties. Weak correlation connection was between $h_{d}$ and $C S$ and between $d_{k}$ and $Q u$, and $B S$ and MOE (Table 4$)$. At higher point ( $60 \%$ of tree's height $), d_{1.3}, l_{k}$ and $d_{k}$ significantly $(p<0.05)$ correlated with all properties. With $d_{1.3}$, the strongest correlated was $C S$ (the highest value of correlation coefficient at $p<0.05$ ) and slightly weaker $B S$ (smaller coefficient value). With crown width, the strongest correlated was $M O E$, and the weakest $Q u$ (Table 4).

In highest part of shaft ( $80 \%$ of tree's height), wood properties in the smallest degree correlated with analysed trees features. Significant correlation coefficient $(p<0.05)$ was only between $d_{1.3}$ and MOE (Table 4).

\section{Discussion}

The aim of this study was to define the relations that occur between juvenile wood properties and chosen features of stem and crown of Scots pine. Analysed was inter alia basic density, compressive strength along fibres, static bending strength and modulus of elasticity in bending. From tree's features chosen were: dbh, trees height, length and width of crown. In case of basic density, its general value was defined on $416 \mathrm{~kg} / \mathrm{m}^{3}$ level, which is a comparable result to the result obtained by Tomczak et al. (2010) and Gryc et al. (2011). Average compressive strength along fibres of Scots pine juvenile wood amounts to $22.3 \mathrm{MPa}$. Static compressive strength was $45.8 \mathrm{MPa}$ and modulus of elasticity was $4726 \mathrm{MPa}$. Similar values of juvenile wood strength obtained inter alia Pikk and Kask (2004) and Tomczak and Jelonek (2012). Examined trees were characterised with dbh of around $34 \mathrm{~cm}$, height of $26 \mathrm{~m}$, crown 7.8-m long and crown's diameter $3.8 \mathrm{~m}$. These dimensions of stem and crown are typical for pine in this age (Kaźmierczak 2009, Turski et al. 2012).

Analysed wood properties, both in general approach and with stem's division to parts in different degrees, correlated with tree's features. All coefficients had negative value, which means that with the increment of tree's dimensions, the properties of juvenile wood worsen. Diversity of juvenile wood properties results from diversity of trees increment in thickness dynamics. Usually, trees thicker, higher, with larger crowns, occupying in forest stands more favourable biosocial position increase faster than thinner, smaller trees with smaller crowns (Lemke 1966, 1968).

One of the assumptions of conducted analysis was correlating properties of juvenile wood from different parts of stem, i.e. produced in different tree's life periods, with its dimensions in mature age. Despite apparent lack of relation, it turned out that properties of juvenile wood produced in different tree's life periods correlate with trees' biometric features in mature age (in particular with dbh and crown's length). dbh is a consequence of tree's growth in thickness. The dynamics of this process will depend notably on the technical parameter values. Length of crown is, in case of pine, a feature considered to be one of the most important coefficients of tree's stability (Jelonek et al. 2013). Due to the fact that elements of tree's biomechanical system are both tree's biometric features and wood properties, stated correlations seems to be an effect of natural genetically conditioned development schemes. Trees differentiation in terms of biometric features (biosocial) starts in very early stage of forest stand's development. Possible drop of advancement of biosocial position concerns around $40 \%$ of trees (Beker 2008). It can be assumed that with the majority of trees in forest stands, starting from early development stages, produced is wood tissue with structure and parameters adequate for mature tree's dimensions.

Juvenile wood is often called a wood formed in this part of stem, which is the living part of crown (crown-formed wood; Paul 1957). Tomczak et al. (2007) analysed the scope of mature wood on longitudinal section of Scots pine stem and stated that for estimation of mature wood range, crown's diameter can be used and crown's length in this case is useless. In case of wood properties, prediction can be based also on crown's diameter and length.

Tree's development is a constant increase of its dimensions and mass. Under mass influence, especially crown's mass, the stem undergoes strong static and dynamic tensions. Those tensions cause cambium reaction, which can lead to changes in structure and wood properties and also to changes in stem's shape (Telewski 1995; Robertson 1991; Tomczak et al. 2012), including most of all its lower part. In top part, static and dynamic tensions are smaller. Knowing the rule about creating maximally durable structure with the smallest energetic expanse possible, explained can be inter alia axial variability of juvenile wood properties. Values of all technical parameters generally decreased with an increase in distance from stem's base, which is also a specific feature of general wood variability in Scots pine stem (Helińska-Raczkowska and Fabisiak 1994; Repola 2006; Ikonen et al. 2008; Witkowska and Lachowicz 2013).

As obtained results indicate, many relations occur between tree's features and properties of tissues. Properties of pine's juvenile wood correlate mainly with dbh and crown's length and in the central part of stem also with 
crown's diameter, which quite significantly influences on tree's stability. From the relations mentioned above it may result that juvenile wood is a significant element of a tree's biomechanical system. It is one of the numerous wood modifications or processes optimising organ's structure, whose main task is to transfer statistic and dynamic loads and also transport water. In this sense, tree's stem is like a complex beam, which is built-up of tissue of different properties, depending on tree's development stage (dimensions) in which it was formed.

\section{Results}

Wood properties analysed both in general approach and with stem's division into parts in different degrees correlated with tree's features. All coefficients had negative values, which means that the trees of bigger dimensions form juvenile wood with worse properties.

Properties of juvenile wood formed in different periods of tree's life connected were in particular with dbh and crown's length. In small degree, they correlated with tree's height. With crown's diameter, it significantly correlated with the properties of wood from the middle part of the stem.

\section{Acknowledgements}

The study carried out with financial support of National Science Centre as a part of project NN 309108240 'Influence of load of trees by the wind to the diversity of selected technical parameters of the wood of Scots pine (Pinus sylvestris L.)'.

\section{References}

Amarasekara H., Denne M. P. 2002. Effects of crown size on wood characteristics of Corsican pine in relation to definitions of juvenile wood, crown formed and core wood. Forestry, 75(1): 51-61.

Beker C. 2008. Zmiana struktury biosocjalnej w niepielęgnowanych drzewostanach sosnowych [Changes in the biosocial structure of unthinned Scots pine stands]. Sylwan, 5: 44-51.

Gryc V., Vavrčik H., Horn K. 2011. Density of juvenile and mature wood of selected coniferous species. Journal of Forest Science, 57(3): 123-130.

Hanrup B., Danell Ö., Ekberg I., Moëll M. 2001. Relationship between wood density and tracheid dimension in Pinus sylvestris L. Wood and Fiber Science, 32(2): 173-181.

Helińska-Raczkowska L., Fabisiak E. 1994. Zmienność wybranych cech budowy drewna młodocianego drewna sosny wzdłuż wysokości drzew. Roczniki Akademii Rolniczej w Poznaniu, 262: 3-13.

Fabisiak E. 2005. Zmienność podstawowych elementów anatomicznych i gęstości drewna wybranych gatunków drzew. Roczniki Akademii Rolniczej w Poznaniu, Rozprawy Naukowe, 369: 1-176

Fries A., Ericsson T. 2006. Estimating genetic parameters for wood density of Scots pine (Pinus sylvestris L.). Silvae Genetica, 55(2): 84-92.

Hejnowicz Z. 2002. Anatomia i histogeneza roślin naczyniowych. Warszawa, PWN. ISBN 83-01-13825-4.

Ikonen V.-P., Peltola H., Wilhelmsson L, Kilpeläinen L, Väisänen H., Nuutinen T., Kellomäki S. 2008. Modelling the distribution of wood properties along the stems of Scots pine (Pinus sylvestris L.) and Norway spruce (Picea abies (L.) Karst.) as affected by silvicultural management. Forest Ecology and Management, 256: 1356-1371.

Jakubowski M. 2004. Proportion of juvenile and mature wood in stems of Norway spruce (Picea abies (L.) Karst.) versus the volume of tree crowns. Annals of Warsaw Agriculture University - SGGW, Forestry and Wood Technology, 55: 254-258.

Jelonek T., Walkowiak R., Jakubowski M., Tomczak A. 2013. Wskaźniki stabilności drzew w drzewostanach sosnowych uszkodzonych przez wiatr [Indices of tree stability in Scots pine stands damaged by wind]. Sylwan, 157(5): 323-329.

Kaźmierczak K. 2009. Wybrane miary przestrzeni wzrostu pojedynczego drzewa w bliskorębnym drzewostanie sosnowym. Sylwan, 153(5): 298-303.

Kraft G. 1884. Beiträge zur Lehre von den Durchforstungen, Schlagstellungen und Lichtungshieben. Hannover, Klindworth.

Kučera B. 1994. A hypothesis relating current annual height increment to juvenile wood formation in Norway spruce. Wood and Fiber Science, 26: 154-167.

Lemke J. 1966. Korona jako kryterium oceny dynamiki wzrostowej drzew w drzewostanie sosnowym. Folia Forestalia Polonica, Series A, 12: 185-236.

Lemke J. 1968. Związek pomiędzy wielkością korony a przyrostem drzew w drzewostanach sosnowych. Prace Komisji Nauk Rolniczych i Komisji Nauk Leśnych PTPN, 25: 1-48.

Mansfield S. D., Parish R., Goudie J. W., Kang K.-Y., Ott P. 2007. The effects of crown ratio on the transition from juvenile to mature wood production in lodgepole pine in western Canada. Canadian Journal of Forest Research, 37(8): 1450-1459.

Mutz R., Guilley E., Sauter U. H., Nepveu G. 2004. Modeling juvenile-mature wood transition in Scots pine (Pinus sylvestris L.) using nonlinear mixed-effects models. Annals Forest Science, 61: 831-841.

Paul B. H. 1957. Juvenile wood in conifers. FPL Rep. 2094, Madison, WI: U.S. Department of Agriculture, Forest Service, Forest Products Laboratory. 6 p.

Pazdrowski W. 2004. The proportion and some selected physical and mechanical properties of juvenile, maturing and adult wood of black pine and Scots pine. EJPAU 7 (1) \#03. 
Pazdrowski W., Jakubowski M. 2000. Objętość korony a udział drewna młodocianego w strzale sosny zwyczajnej (Pinus sylvestris L.) Materiały III Konferencji Leśnej. Warszawa, IBL, 268-273.

Pazdrowski W., Spława-Neyman S. 1997. Macrostructure of Scots pine wood from unripe forest stands grown in conditions of fresh forest. Folia Forestalia Polonica, Series $B, 28: 41-46$.

Pazdrowski W., Tomczak A., Jelonek T., Duma M., Szaban J., Jakubowski M. 2007. The effects of live crown reduction during artificial pruning on share of juvenile wood tissue in stems of Scots pines (Pinus sylvestris L.). Annals of Warsaw Agriculture University - SGGW, Forest and Wood Technology, 62: 126-129.

Pikk J., Kask R. 2004. Mechanical properties of juvenile wood of Scots pine (Pinus sylvestris L.) on myrtillus forest site type. Baltic Forestry, 10(1): 72-78.

PN-63/D-04117 Fizyczne i mechaniczne właściwości drewna. Oznaczanie współczynnika sprężystości przy zginaniu statycznym.

PN-77/D-04101 Drewno. Oznaczanie gęstości.

PN-77/D-04103 Drewno. Oznaczanie wytrzymałości na zginanie statyczne.

PN-79/D-04102 Drewno. Oznaczanie wytrzymałości na ściskanie wzdłuż włókien.

Repola J. 2006. Models for vertical wood density of Scots pine, Norway spruce and birch stems, and their application to determine average wood density. Silva Fennica, 40(4): 673-685.

Robertson A. 1991. Centroid of wood density, bole eccentricity, and tree-ring width in relation to vector winds in wave forests. Canadian Journal of Forest Research, 21(1): 73-82.

Telewski F. W. 1995. Wind-induced physiological and developmental responses in trees. In: Cottus M. P., Grace J. (Eds.) Wind and Trees: 237-263.

Tomczak A., Jelonek T. 2012. Parametry techniczne młodocianego i dojrzałego drewna sosny zwyczajnej [Technical parameters of juvenile and mature wood in Scots pine (Pinus sylvestris L.)]. Sylwan, 156(9): 695-702.

Tomczak A., Jelonek T., Pazdrowski W. 2012. Ekscentryczność pni sosny zwyczajnej (Pinus sylvestris L.) z drzewostanów silnie eksponowanych na wiatr [Pine (Pinus sylvestris L.) trunk irregularity due to exposure to wind]. Forestry Letters, 103: 41-46.

Tomczak A., Jelonek T., Pazdrowski W., Duma M. 2005. Selected biometric traits of the Scots pine (Pinus sylvestris L.) stems as the basis for the assessment of the volume and proportion of mature wood. Acta Scientiarum Polonorum Silvarum Colendarum Ratio et Industria Lignaria, 4(2): 113-121.

Tomczak A., Jelonek T., Zoń L. 2010. Porównanie wybranych właściwości fizycznych drewna młodocianego i dojrzałego sosny zwyczajnej (Pinus sylvestris L.) z drzewostanów rębnych. Sylwan, 154(12): 809-817.

Tomczak A., Pazdrowski W., Jelonek T. 2007a. Distribution of intermediate and mature wood on the longitudinal cross section of the tree stem and selected biometric traits of the Scots pine (Pinus sylvestris L.). Baltic Forestry, 13(1): 116-125.

Tomczak A., Pazdrowski W., Jelonek T., Stypuła I. 2006. Selected biometric traits of Scots pine tree stems developer in conditions of the fresh coniferous forest as the basis of the evaluation of juvenile wood volume. Annals of Warsaw Agriculture University - SGGW, Forestry and Wood Technology, 59: 311-315.

Tomczak A., Pazdrowski W., Jelonek T., Stypuła I. $2007 \mathrm{~b}$. Vertical variability of selected macrostructural properties of juvenile wood organization in stems of Scots pine (Pinus sylvestris L.) trees. Acta Societatis Botanicorum Poloniae, 76(1): 27-33.

Turski M., Jaszczak R., Deus R. 2012. Wybrane charakterystyki koron drzew i ich związek z pierśnicą oraz wysokością w drzewostanach sosnowych różnych klas wieku Selected features of tree crowns and their relationship with the dbh and height in pine tree-stands of different age classes]. Sylwan, 156(5): 369-378.

Wąsik R. 2010. Związki między wybranymi parametrami korony a cechami makrostruktury i gęstością drewna daglezji zielonej (Pseudotsuga menziesii var. viridis Franco) [Relationships between selected crown parameters and the macrostructure properties and density of Douglas fir (Pseudotsuga menziesii var. viridis Franco) Wood]. Sylwan, 154(11): 783-790.

Witkowska J., Lachowicz H. 2013. Zmienność gęstości umownej drewna sosny zwyczajnej (Pinus sylvestris L.) w zależności od wybranych czynników [Variability of conventional wood density of Scots pine (Pinus sylvestris L.) depending on the selected factors]. Sylwan, 157(5): 336-347.

Verkasalo E. 1992. Relationships of the modulus of elasticity and the structure of Finnish Scots pine. Silva Fennica, 26(3): 155-168.

Zajączkowska U. 2006. Optymalizacja kształtu i struktury drzewa według teorii jednorodnego rozkładu naprężeń [Optimization of tree structure and shape according to axiom of uniform stress]. Sylwan, 4: 53-58.

Zobel B. J., Sprague J. R. 1998. Juvenile wood in forest trees. Berlin - Heidelberg - New York, Springer Verlag. 